\title{
PENGARUH INTEGRITAS DAN KECERDASAN EMOSIONAL TERHADAP KINERJA ANGGOTA POLSEK CIKARANG TIMUR
}

\author{
Dinda Mutiara Pratiwi'; Arif Fadila ${ }^{2}$ \\ Universitas Singaperbangsa Karawang \\ dinda.mutiara16112@student.unsika.ac.id ${ }^{1}$;
}

\begin{abstract}
ABSTRAK
Penelitian ini bertujuan untuk menguji dan menganalisis tentang Pengaruh Integritas dan Kecerdasan Emosional terhadap Kinerja Anggota Kepolisian Polsek Cikarang Timur. Penelitian ini dilakukan dengan menggunakan metode deskriptif dan verifikatif. Teknik analisis yang digunakan yaitu teknik analisis skala likert dengan menggunakan alat bantu Microsoft Excell dan Smart PLS 3.0. Hasil penelitian menunjukkan bahwa pengaruh secara parsial Integritas (X1) terhadap kinerja karyawan sebesar 47,2\% dengan arah positif, selanjutnya pengaruh secara parsial Kecerdasan Emosional (X2) terhadap Kinerja (Y) sebesar 45,4\% dengan arah positif. Berdasarkan pengaruh parsial dapat diketahui bahwa kecerdasan emosional (X2) lebih rendah dari Integritas (X2), maka dapat dinyatakan bahwa integritas (X1) lebih banyak memberikan kontribusi terhadap Kinerja (Y) dibandingkan Kecerdasan Emosional (X2). Berdasarkan hasil pengujian yang dilakukan secara simultan melalui boostrapping-R-Square dapat diketahui nilai $\mathrm{R}$ Square sebesar 0,816 dan termasuk keadaan kriteria kuat. Artinya pengaruh variabel Integritas (X1) dan Kecerdasan Emosional (X2) terhadap Kinerja (Y) sebesar $81,6 \%$ dan sisanya sebesar $18,4 \%$ dijelaskan oleh variabel lain yang tidak diteliti dalam penelitian ini.
\end{abstract}

\section{Kata Kunci: Integritas; Kecerdasan Emosional; Kinerja}

\begin{abstract}
This study aims to test and analyze the effect of integrity and emotional intelligence on the performance of members of the Cikarang Timur Police. This research was conducted using descriptive and verification methods. The analysis technique used is the Likert scale analysis technique using tools, Microsoft Excel and Smart PLS 3.0. The results showed that the partial influence of Integrity (X1) on employee performance was $47.2 \%$ in a positive direction, then the partial influence of Emotional Intelligence (X2) on performance $(Y)$ was $45.4 \%$ in a positive direction. Based on the partial effect, it can be seen that emotional intelligence $(X 2)$ is lower than integrity $(X 2)$ so it can be stated that integrity $(X 1)$ contributes more to performance $(Y)$ than Emotional Intelligence (X2). Based on the results of tests carried out simultaneously through boostrapping - R-Square, it can be seen that the $R$ Square value is 0.816 and is a strong criterion. This means that the influence of the variables of Integrity (X1) and Emotional Intelligence $(X 2)$ on performance $(Y)$ is $81.6 \%$ and the remaining $18.4 \%$ is explained by other variables not examined in this study.

Keywords: Integrity; Emotional Intelligence; Performance

PENDAHULUAN

Sumber daya manusia (SDM) yaitu hal terpenting dalam organisasi, organisasi tidak dapat berjalan jika tidak

memiliki SDM. SDM yang berkompeten akan sangat berpengaruh untuk kemajuan organisasi, SDM yang kompeten akan bekerja secara maksimal hingga dapat meningkatkan
\end{abstract}


produktifitas suatu organisasi. Menurut Spencer (Sudaryo, Ariwibowo, \& Sofiati, 2018:178), kompetensi adalah bagian dari kepribadian individu yang relatif dan stabil, dapat dilihat serta diukur dari perilaku individu yang bersangkutan, di tempat kerja ataupun dalam berbagai situasi. Salah satu hal yang berpengaruh terhadap kinerja anggota POLRI yaitu integritas.

Menurut Gea dalam (Sukmana \& Indarto, 2018), integritas merupakan sesuatu yang bersangkutan dengan individu dan bukan organisasi. Individu yang mempunyai integritas yang tinggi merupakan individu yang dapat dipercaya dan dapat diandalkan. Integritas berpengaruh terhadap kinerja anggota, maka semakin tinggi integritas akan semakin bagus pula pencapaian kinerjanya (Wigiadi \& Sunyoto, 2017). Untuk mengetahui fenomena yang terjadi, maka peneliti melakukan pra penelitian di tempat penelitian. Berdasarkan hasil pra penelitian yang dilakukan oleh peneliti, terdapat 3 indikator dengan jumlah responden 3 terbesar yang memilih pernyataan tidak setuju (TS) yaitu indikator dengan pernyataan "Rekan kerja saya selalu mengatakan hal yang sebenarnya walaupun hal tersebut dapat merugikan dirinya sendiri", hal ini menunjukan bahwa responden merasa bahwa rekan kerjanya tidak selalu mengatakan hal yang sebenarnya walaupun hal tersebut dapat merugikan. Indikator selanjutnya yaitu indikator dengan pernyataan "Saya dapat mengendalikan emosi saya di setiap kondisi". Indikator selanjutnya yaitu indikator dengan pernyataan "Saya selalu memberitahukan kepada rekan kerja saya agar rekan kerja saya selalu mematuhi nilai dan norma yang berlaku di Polsek Cikarang Timur".

Faktor selanjutnya yang mempengaruhi kinerja Polri adalah kecerdasan emosional masing-masing individu. Menurut Salovey \& Mayer dalam (Rizky Kurniansyah, 2016), kecerdasan emosional yaitu keahlian psikis yang mendukung individu untuk mengetahui emosi diri dan masyarakat. Seorang individu yang memiliki emotional intelligence yang baik akan dapat mengendalikan perasaannya saat bekerja dan dapat memahami perasaan orang lain.

Berdasarkan hasil pra penelitian yang dilakukan oleh peneliti, terdapat 3 indikator dengan jumlah responden 3 terbesar yang memilih pernyataan tidak setuju (TS) yaitu indikator dengan pernyataan "Saya membiarkan rekan kerja saya mengetahui tentang prinsip dan nilai-nilai yang ada pada diri saya dan tidak membeda-bedakan rekan kerja". Indikator selanjutnya yaitu indikator dengan pernyataan "Dalam keadaan yang sulit, saya tetap tenang dalam menghadapinya". Indikator selanjutnya yaitu indikator dengan pernyataan "Saya bisa mengajak rekan kerja untuk menjadi pribadi yang lebih baik lagi”.

Demi mencapai kinerja yang baik, maka organisasi harus mencari SDM yang kompeten dan profesional dalam 
melaksanakan tugas yang diberikan. Kinerja pegawai yang tinggi akan mendukung produktivitas organisasi, sehingga sudah seharusnya pimpinan organisasi senantiasa memperhatikan peningkatan kinerja anggotanya demi kemajuan organisasi (Dunggio, 2020). Menurut Peraturan Kepala Kepolisian Negara Republik Indonesia No. 11 (2012), kinerja merupakan proses manajemen untuk menilai tingkat pencapaian indikator kinerja yang membandingkan target kinerja dengan realisasi kinerja. Kinerja individu ini akan tercapai apabila didukung oleh atribut individu, upaya kerja dan dukungan organisasi (Hadju \& Adam, 2019).

Berdasarkan hasil pra penelitian yang dilakukan oleh peneliti, terdapat 3 indikator dengan jumlah responden 3 terbesar yang memilih pernyataan tidak setuju (TS) yaitu indikator dengan pernyataan "Saya tidak mampu bekerjasama dengan pimpinan saya". Indikator selanjutnya yaitu indikator dengan pernyataan "Saya dapat memberikan gagasan baru kepada Polsek Cikarang Timur". Indikator selanjutnya yaitu indikator dengan pernyataan "Saya selalu merasa empati terhadap apa yang terjadi pada rekan kerja saya".

Menurut Peraturan Kepala Kepolisian Negara Republik Indonesia No. 2 (2018), Polri adalah alat negara yang berperan dalam memelihara keamanan dan ketertiban masyarakat, menegakkan hukum serta memberikan perlindungan, pengayoman dan pelayanan kepada masyarakat dalam rangka terpeliharanya keamanan dalam negeri. Polsek Cikarang Timur merupakan bagian dalam satuan kepolisian yang berada di Sektor Cikarang Timur Kabupaten Bekasi. Polsek Cikarang Timur memiliki tujuan untuk selalu menjadi ProMoTer yang merupakan arti dari kata Profesional, Modern dan Terpercaya dalam menjalankan tugas-tugas yang sudah menjadi tanggung jawab oleh seluruh anggota Kepolisian Polsek Cikarang Timur guna mencapai kinerja yang baik.

\section{KAJIAN LITERATUR}

\section{A. Integritas}

Menurut Phill Prile dalam (Wigiadi \& Sunyoto, 2017), integrasi berasal dari perilaku tidak mendahulukan diri sendiri, dibangun dengan dasar disiplin, menepati komitmen bahkan saat merugikan diri sendiri, tetap patuh pada komitmen bahkan ketika itu tidak nyaman.

Menurut Rogers (Pangabean, 2017), faktor-faktor yang mempengaruhi terbentuknya integritas yaitu:

1. Jujur, yaitu tidak menghindari perasaan, berbahasa dan betindak sama dengan nilai pribadi yang dijunjung, menjaga kepercayaan pada orang lain.

2. Teguh, yaitu patuh dalam melaksanakan kewajiban, sulit untuk melakukan perbuatan tidak baik 
walaupun muncul rayuan materi atau paksaan dari orang sekitar.

3. Mempunyai kemampuan mengontrol diri, individu dapat mengatur atau mengawasi perilaku supaya sama dengan target hidup dan moral yang dimiliki.

4. Mempunyai self-esteem, yaitu keyakinan seseorang bisa berperilaku selaras dengan nilai yang diyakini.

\section{B. Kecerdasan Emosional}

Menurut Wibowo (Ridhawati, 2016), menyatakan, kecerdasan emosional yaitu kecerdasan dalam memakai emosi sesuai apa yang diinginkan, keahlian untuk mengatur emosi agar dapat meninggalkan pengaruh baik. Menurut Goleman (Sudaryo, Ariwibowo, \& Sofiati, 2018:97), terdapat empat dimensi kecerdasan emosional yaitu:

1. Self Awareness, adalah kecakapan membaca perasaan diri dan mengetahui dampak dari penggunaan perasaan emosi ketika mengambil keputusan. Indikator dalam Self Awareness adalah Emotional Self Awareness, Accurate Self Assessment $\&$ Self Confidence.

2. Self Management (manajemen diri), yaitu keahlian mengendalikan perasaan dan hasrat diri lalu dapat beradaptasi terhadap perubahan lingkungan. Indikator dalam self management adalah: Self Control, Trustworthiness, Conscientiousness, Adaptability, Achievement Orientation and Initiative (inisiatif).
3. Social Awareness (kesadaran sosial), yaitu kemampuan agar merasakan, memahami dan respon pada perasaan orang lain sewaktu memahami jaringan sosial di sekitar kita. Indikator dalam Social Awareness yaitu: Empathy (empati), Service Orientation (berorientasi pada pelayanan) dan Organization Awareness (kesadaran organisasi).

4. Relationship Management (manajemen hubungan), yaitu keahlian dalam menginspirasikan, mempengaruhi dan memajukan orang sekitar pada saat menangani konflik. Indikator dalam Relationship Management adalah: Developing Others, Influence, Communication, Conflict Management, Leadership, Change Catalyst, Buolding Bonds and Teamwork and Collaboration.

\section{Kinerja}

Menurut Peraturan Kepala Kepolisian Negara Republik Indonesia No. 2 (2018), kinerja adalah hasil kerja yang dicapai oleh setiap anggota Polri pada satuan kerja/satuan fungsi/satuan wilayah sesuai dengan faktor generik dan faktor spesifik. Mangkunegara dalam Sopiah dan Sangadji Etta Mamang (2018:350) mendefinisikan kinerja sebagai pencapaian kerja oleh pegawai dalam melaksanakan kewajiban yang diberikan kepadanya secara kualitas dan kuantitas.

Menurut PERPOL No. 2 Tahun 2018 pasal 15, perilaku kerja anggota (PKA) merupakan indikator penilaian 
yang terkait dengan faktor kinerja dan standar kinerja yang telah ditentukan, yang diberlakukan sama untuk seluruh anggota Polri, penilaian PKA meliputi: kepemimpinan, orientasi pelayanan, komunikasi, pengendalian emosi, integritas, empati, komitmen terhadap organisasi, inisiatif, disiplin dan kerjasama.

Penelitian ini bertujuan untuk mengetahui tentang Pengaruh secara parsial dan simultan antara Integritas (X1) dan Kecerdasan Emosional (X2) terhadap Kinerja (Y) Anggota Kepolisian Polsek Cikarang Timur.

\section{PERMASALAHAN}

Berdasarkan uraian di atas, maka dapat dirumuskan permasalahan:

1. Bagaimana Integritas Anggota Kepolisian Polsek Cikarang Timur?

2. Bagaimana Kecerdasan Emosional Anggota Kepolisian Polsek Cikarang Timur?

3. Bagaimana Kinerja Anggota Kepolisian Polsek Cikarang Timur?

4. Bagaimana pengaruh Integritas secara parsial terhadap Kinerja Anggota Kepolisian Polsek Cikarang Timur?

5. Bagaimana pengaruh Kecerdasan Emosional secara parsial terhadap Kinerja Anggota Kepolisian Polsek Cikarang Timur?

6. Seberapa besar pengaruh antara Integritas dan Kecerdasan Emosional secara simultan terhadap Kinerja
Anggota Kepolisian Polsek Cikarang Timur?

\section{METODE PENELITIAN}

Metode yang digunakan dalam penelitian yaitu metode deskriptif dan verifikatif, yaitu hasil penelitian lalu diolah dan ditarik kesimpulan. Dengan menggunakan metode penelitian ini, akan diketahui relasi yang signifikan antarvariabel penelitian lalu menciptakan kesimpulan yang akan memperjelas gambaran mengenai objek penelitian. (Sugiyono, 2018:226) menjelaskan, metode deskriptif yaitu proses yang dipakai dalam mengkaji data dengan menggambarkan data yang terkumpul sesuai fakta tanpa bertujuan menarik kesimpulan untuk umum. Menurut (Nazir, 2011:91), metode verifikatif merupakan suatu proses penelitian yang bermaksud agar memahami relasi per-variabel dengan pengujian hipotesis menggunakan perhitungan statistik, lalu dapat menciptakan bukti yang menunjukkan hipotesis ditolak atau diterima.

Pada penelitian ini responden (sampel) yang dipilih dari populasi yaitu seluruh anggota Kepolisian Polsek Cikarang Timur yaitu sebanyak 59 anggota. Penelitian dengan populasi di bawah 100 menggunakan teknik sensus, maka seluruh populasi dijadikan sebagai sampel / menjadi responden pemberi informasi (Sugiyono 2018:140). 


\section{Teknik Pengumpulan Data}

Penelitian ini memakai prosedur pengumpulan data langsung di lapangan yaitu:

1. Interview

Sugiyono (2018:214), wawancara menjadi teknik pengumpulan data jika peneliti akan mengadakan pra penelitian demi mendeteksi persoalan yang dapat diteliti dan jika peneliti ingin mengetahui sesuatu dari responden lebih detail dan jumlah respondennya sedikit.

2. Kuesioner (Angket)

Sugiyono (2018:219), angket yaitu metode mengumpulkan data yang dilaksanakan melalui pertanyaan atau pernyataan tertulis untuk responden lalu dijawabnya.

3. Observasi

Sugiyono (2018:223), observasi yaitu teknik pengumpulan data dengan karakterter perinci dari pada teknik yang lain yaitu wawancara \& kuesioner. Pada penelitian ini, kegiatan observasi yang dipakai untuk mengamati fenomena yang menarik lalu dijadikan sebagai penelitian.

\section{Uji Validitas}

Menurut (Hussein, 2015), uji validitas dalam Partial Least Square terdapat dua tahapan yang harus dilakukan yaitu:

1. Convergent Validity, adalah nilai loading faktor pada variabel laten dengan indikator-indikator. Nilai yang diharapkan yaitu sebesar $>0.7$.
Variabel laten yaitu variabel yang nilai kuantitatifnya tidak dapat diketahui secara tampak. Menurut Sofyani $\quad(2016: 15) \quad$ kriteria Convergent Validity yaitu: Outer Loading $\geq 0,7$ dan Average Variance Extracted $\geq 0,5$.

2. Discriminant Validity, adalah nilai cross loading faktor yang berguna untuk mengetahui apakah konstruk memiliki diskriminan yang memadai yaitu dengan cara membandingkan nilai loading pada konstruk yang dituju harus lebih besar dibandingkan dengan nilai loading konstruk lainnya.

\section{Uji Reliabilitas}

Menurut Hussein (2015), data yang memiliki nilai composite reliability $>0.7$ yaitu data yang memiliki reliabilitas yang tinggi. Kriteria nilai composite reliability yaitu : Composite Reliability $\geq 0.7$ dan Cronbach Alpha $\geq 0.6$.

\section{Uji Hipotesis}

Dalam pengujian hipotesis maka akan diketahui suatu hipotesis diterima atau ditolak. Kriteria penerimaan hipotesis yaitu :t-tabel > 1,96 dan Probability Value (p-value) $<0,05$. 
Pengaruh Parsial Integritas (X1) Terhadap Kinerja (Y)

$$
\begin{array}{ll}
\mathrm{H}_{0}: \mathrm{Pyx}_{1}=0 & \text { Tidak terdapat pengaruh parsial integritas terhadap } \\
& \text { kinerja. } \\
\mathrm{H}_{1}: \mathrm{Pyx}_{1} \neq 0 & \begin{array}{l}
\text { Terdapat pengaruh parsial integritas terhadap } \\
\text { kinerja. }
\end{array}
\end{array}
$$

\section{Pengaruh Kecerdasan Emosional (X2) Terhadap Kinerja (Y)}

$$
\begin{array}{ll}
\mathrm{H}_{0}: \mathrm{Pyx}_{2}=0 & \text { Tidak terdapat pengaruh parsial kecerdasan } \\
& \text { emosional terhadap kinerja. } \\
\mathrm{H}_{1}: \mathrm{Pyx}_{2} \neq 0 & \begin{array}{l}
\text { Terdapat pengaruh parsial kecerdasan emosional } \\
\text { terhadap kinerja }
\end{array}
\end{array}
$$

\section{Pengaruh Simultan Integritas (X1) Dan Kecerdasan Emosional (X2) Terhadap} Kinerja (Y).

$$
\begin{array}{ll}
\mathrm{H}_{0}: \mathrm{Pyx}_{1}, \mathrm{Pyx}_{2},=0 & \text { Tidak terdapat pengaruh simultan antara } \\
& \begin{array}{l}
\text { Integritas dan Kecerdasan Emoisonal terhadap } \\
\text { kinerja. }
\end{array} \\
\mathrm{H}_{1}: \mathrm{Pyx}_{1}, \mathrm{Pyx}_{2}, \mathrm{Pyx}_{3} \neq 0 & \text { Terdapat pengaruh simultan antara Integritas dan } \\
& \text { Kecerdasan Emosional terhadap kinerja. }
\end{array}
$$

\section{HASIL PENELITIAN DAN PEMBAHASAN}

\section{Hasil Uji Validitas}

1. Convergent Validity

Berikut adalah hasil pengujian PLS Algorithm - Outer Loading:

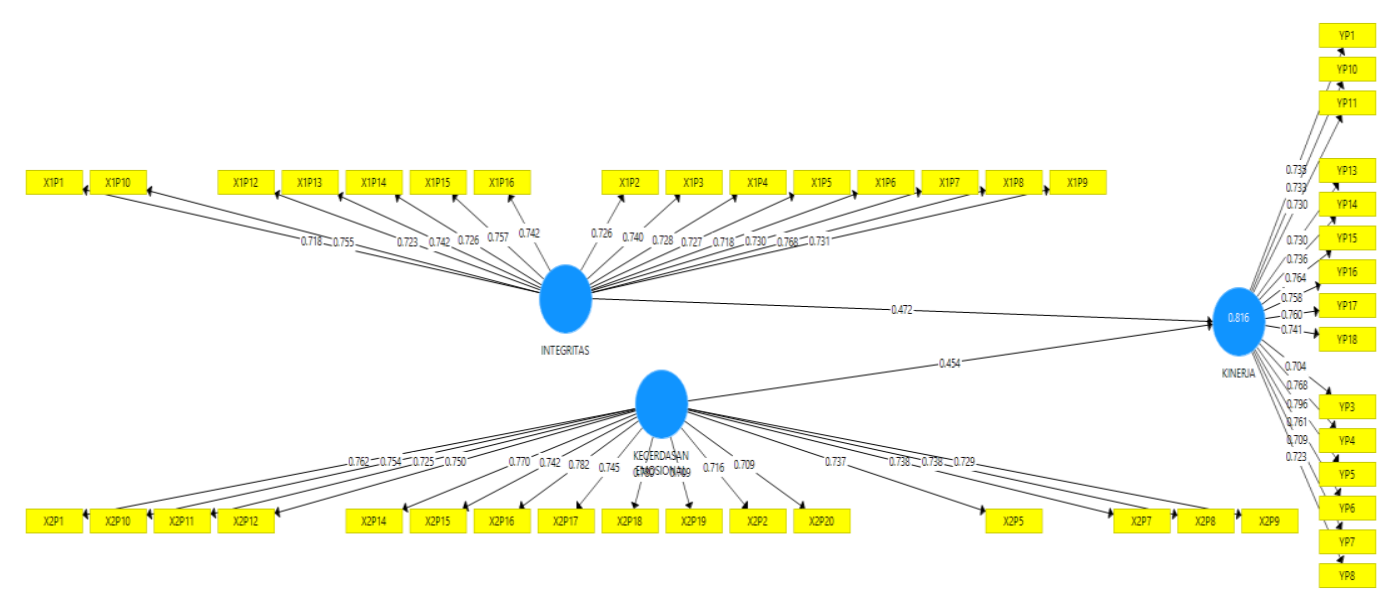

Gambar 1.

Diagram Jalur PLS-SEM

Sumber: Diolah Peneliti, 2020 
Gambar 1 yaitu hasil pengujian validitas setelah beberapa pernyataan sebelumnya yang tidak valid $(<0,7)$ telah dihapus dan pada gambar 1 menunjukkan bahwa seluruh pernyataan sudah di atas 0,7 dan sudah valid.

Setelah seluruh pernyataan dinyatakan valid, maka langkah selanjutnya adalah melakukan pengujian PLS Algorithm-AVE (Average Variance Extracted) dengan hasil sebagai berikut: Integritas memiliki nilai $A V E$ sebesar $0,541 \geq 0,5$ (Valid), Kecerdasan Emosional memiliki nilai $A V E$ sebesar $0,553 \geq 0,5$ (Valid) dan Kinerja memiliki nilai $A V E$ sebesar $0,553 \geq 0,5$ (Valid).

\section{Discriminant Validity}

Berdasarkan pengujian pengujian PLS Algorithm-Cross Loading dapat menjelaskan bahwa seluruh pernyataan memiliki nilai loading > cross loading artinya seluruh pernyataan dapat dinyatakan valid karena telah memenuhi kriteria yang telah ditetapkan. Tahapan selanjutnya dilakukan pengujian PLS Algorithm - Fornell-Larcker dengan hasil sebagai berikut:

Tabel1. Hasil Pengujian PLS Algorithm - Fornell-Larcker

\begin{tabular}{|c|c|c|c|c|}
\hline Variabel & Integritas & $\begin{array}{c}\text { Kecerdasan } \\
\text { Emosional }\end{array}$ & Kinerja & Keterangan \\
\hline Integritas & 0,736 & & & Valid \\
\hline Kecerdasan Emosional & 0,902 & 0,743 & & Valid \\
\hline Kinerja & 0,882 & 0,880 & 0,744 & Valid \\
\hline
\end{tabular}

Sumber : Diolah Peneliti, 2020

Berdasarkan tabel 1 dapat diketahui bahwa nilai terhadap variabelnya sendir i> dari nilai terhadap variabel lainnya, maka dari itu seluruh variabel dinyatakan valid pada pengujian Fornell-Larcker.

\section{Hasil Pengujian Reliabilitas}

Setelah melakukan uji validitas dan seluruh data dinyatakan valid. maka langkah selanjutnya adalah melakukan pengujian reliabilitas dengan syarat Composite Reliability $\geq 0,7$ dan Cronbach's Alpha $\geq 0,6$. Berikutya itu hasil uji reliabilitas dengan menggunakan software Smart PLS:

Tabel2. Hasil Pengujian Reliabilitas

\begin{tabular}{|c|c|c|c|c|c|}
\hline Variabel & $\begin{array}{c}\text { Composite } \\
\text { Reliability }\end{array}$ & Syarat & $\begin{array}{c}\text { Cronbach's } \\
\text { Alpha }\end{array}$ & Syarat & Keterangan \\
\hline Integritas & 0,946 & $\geq 0,7$ & 0,939 & $\geq 0,6$ & Reliabel \\
\hline $\begin{array}{c}\text { Kecerdasan } \\
\text { Emosional }\end{array}$ & 0,952 & $\geq 0,7$ & 0,946 & $\geq 0,6$ & Reliabel \\
\hline Kinerja & 0,949 & $\geq 0,7$ & 0,942 & $\geq 0,6$ & Reliabel \\
\hline
\end{tabular}

Sumber: Diolah Peneliti, 2020 
Berdasarkan tabel 2 dapat dilihat bahwa seluruh variabel memenuhi syarat yang telah ditetapkan sehingga dapat dikatakan bahwa seluruh variabel reliabel.

\section{Hasil Analisis Deskriptif Variabel Integritas}

Berdasarkan hasil tanggapan responden terhadap indikator-indikator variabel integritas, maka dibuatlah rekapitulasi hasil tanggapan dari indikator-indikator agar mengetahui kriteria rentang skala variabel integritas, berikut hasil rekapitulasi indikatorindikator variabel integritas: 1. Indikator jujur dalam berbicara (diri sendiri) dengan jumlah skor 244 dalam kriteria (setuju), 2. Indikator jujur dalam berbicara (rekan kerja) dengan jumlah skor 243 dalam kriteria (setuju), 3. Indikator jujur dalam berperilaku (diri sendiri) dengan jumlah skor 240 dalam kriteria (setuju), 4. Indikator jujur dalam berperilaku (rekan kerja) dengan jumlah skor 235 dalam kriteria (setuju), 5. Indiktor amanah (amanah) dalam berperilaku (rekan kerja) dengan jumlah skor 215 dalam kriteria (setuju), 6. Indikator amanah (terkadang tidak amanah) dengan jumlah skor 246 dalam kriteria (setuju), 7. Indikator teguh dalam prinsip (sesuai prinsip) dengan jumlah skor 241 dalam kriteria (setuju), 8. Indikator teguh dalam prinsip (terkadang di luar prinsip) dengan jumlah skor 241 dalam kriteria (setuju), 9. Indikator tidak mudah dipengaruhi dengan jumlah skor 225 dalam kriteria (setuju), 10. Indikator patuh terhadap norma dengan jumlah skor 217 dalam kriteria (setuju), 11. Indikator patuh terhadap norma (terkadang tidak patuh), dengan jumlah skor 240 dalam kriteria (setuju), 12. Indikator dapat mengendalikan diri dalam setiap kondisi dengan jumlah skor 209 dalam kriteria (setuju), 13. Indikator menafsirkan suatu keadaan dengan memperhatikan sisi positif secara subjektif dengan jumlah skor 236 dalam kriteria (setuju), 14. Indikator mampu mengendalikan diri dalam mengambil keputusan dengan jumlah skor 214 dalam kriteria (setuju), 15. Indikator bertindak sesuai pada nilai dan norma yang berlaku dengan jumlah skor 228 dalam kriteria (setuju), 16. Indikator memiliki sifat disiplin dengan jumlah skor 242 dalam kriteria (setuju) dan 17. Indikator Dapat mempengaruhi individu untuk mentaati nilai dan norma yang berlaku dengan jumlah skor 235 dalam kriteria (setuju). Berdasarkan jumlah skor seluruh indikator integritas, diperoleh nilai ratarata sebesar 244 (setuju). Hal ini menunjukkan bahwa integritas seluruh anggota Kepolisian Polsek Cikarang Timur berada dalam criteria setuju, artinya integritas seluruh anggota Kepolisian Polsek Cikarang Timur baik.

\section{Hasil Analisis Deskriptif Variabel Kecerdasan Emosional}

Berdasarkan hasil tanggapan responden terhadap indikator-indikator variabel kecerdasan emosional maka 
dibuatlah rekapitulasi hasil tanggapan dari indikator-indikator agar mengetahui criteria rentang skala variabel kecerdasan emosional, berikut hasil rekapitulasi indikator-indikator variabel kecerdasan emosional: 1 . Indikator kesadaran emosional diri dengan jumlah skor 233 dalam kriteria (setuju), 2. Indikator penaksiran diri yang akurat dengan jumlah skor 234 dalam kriteria (setuju), 3. Indikator percaya diri dengan jumlah skor 240 dalam kriteria (setuju), 4. indikator pengaturan diri dengan jumlah skor 239 dalam kriteria (setuju), 5. Indikator kepercayaan dengan jumlah skor 237 dalam kriteria (setuju), 6. indikator tanggung jawab diri dengan jumlah skor 239 dalam kriteria (setuju), 7. indikator adaptasi dengan jumlah skor 219 dalam kriteria (setuju), 8. indikator orientasi pada kesuksesan dengan jumlah skor 239 dalam kriteria (setuju), 9. indikator inisiatif dengan jumlah skor 238 dalam kriteria (setuju), 10. indikator empati dengan jumlah skor 194 dalam kriteria (cukup setuju), 11. indikator orientasi pada pelayanan dengan jumlah skor 235 dalam kriteria (setuju), 12. indikator kesadaran organisasi dengan jumlah skor 212 dalam kriteria (setuju), 13. indikator mengembangkan orang lain dengan jumlah skor 209 dalam kriteria (setuju), 14. indikator mempengaruhi orang lain dengan jumlah skor 200 dalam kriteria (cukup setuju), 15. indikator komunikasi dengan jumlah skor 234 dalam kriteria (setuju), 16. indikator manajemen konflik dengan jumlah skor 198 dalam kriteria (setuju), 17. indikator kepemimpinan dengan jumlah skor 214 dalam kriteria (setuju), 18. indikator mau berubah dengan jumlah skor 190 dalam kriteria (cukup setuju), 19. indikator membangun hubungan dengan jumlah skor 232 dalam kriteria (setuju), 20. indikator kerjasama tim dengan jumlah skor 218 dalam kriteria (setuju). Berdasarkan hasil rekapitulasi indikator variabel kecerdasan emosional diperoleh nilai rata-rata sebesar 223. Hal ini menunjukkan bahwa kecerdasan emosional seluruh anggota kepolisian Polsek Cikarang Timur berada dalam criteria setuju, artinya kecerdasan emosional seluruh anggota Kepolisian Polsek Cikarang Timur sudah baik.

\section{Hasil Analisis Deskriptif Variabel Kinerja}

Berdasarkan hasil tanggapan responden terhadap indikator-indikator variabel kinerja maka dibuatlah rekapitulasi hasil tanggapan dari indikator-indikator agar mengetahui kriteria rentang skala variabel kinerja, berikut hasil rekapitulasi indikatorindikator variabel kinerja: 1. Indikator kepemimpinan (pimpinan) dengan jumlah skor 241 dalam kriteria (setuju), 2. Indikator kepemimpinan (rekan kerja) dengan jumlah skor 234 dalam kriteria (setuju), 3. Indikator orientasi pelayanan (masyarakat) dengan jumlah skor 241 dalam kriteria (setuju), 4. Indikator orientasi pelayanan 
(pimpinan) dengan jumlah skor 242 dalam kriteria (setuju), 5. Indikator orientasi pelayanan (rekan kerja) dengan jumlah skor 242 dalam kriteria (setuju), 6. Indikator komunikasi (masyarakat) dengan jumlah skor 237 dalam kriteria (setuju), 7. Indikator komunikasi (pimpinan) dengan jumlah skor 243 dalam kriteria (setuju), 8. Indikator komunikasi (rekan kerja)dengan jumlah skor 242 dalam kriteria (setuju), 9. Indikator pengendalian emosi dengan jumlah skor 240 dalam kriteria (setuju), 10. Indikator integritas dengan jumlah skor 241 dalam kriteria (setuju), 11. Indikator empati dengan jumlah skor 217 dalam kriteria (setuju), 12. Indikator komitmen terhadap organisasi dengan jumlah skor 244 dalam kriteria (setuju), 13. Indikator inisiatif dengan jumlah skor 281 dalam kriteria (setuju), 14. Indikator disiplin (menyelesaikan tugas tepat waktu) dengan jumlah skor 241 dalam kriteria (setuju), 15. Indikator disiplin (datang tidak tepat waktu) dengan jumlah skor 243 dalam kriteria (setuju), 16. Indikator disiplin (datang tepat waktu) dengan jumlah skor 241 dalam kriteria (setuju), 17. Indikator kerjasama (rekan kerja) dengan jumlah skor 239 dalam kriteria (setuju) dan 18. Indikator kerjasama (pimpinan) dengan jumlah skor 243 dalam kriteria (setuju). Berdasarkan hasil rekapitulasi indikator variabel kinerja diperoleh nilai rata-rata sebesar 242. Hal ini menunjukkan bahwa kinerja seluruh anggota Kepolisian Polsek Cikarang Timur berada dalam criteria setuju, artinya kinerja seluruh anggota Kepolisian Polsek Cikarang Timur sudah baik.

\section{Hasil Pengujian Hipotesis Pengaruh Parsial Integritas (X1) Terhadap Kinerja (Y)}

Berdasarkan hasil pengujian hipotesis pengaruh parsial Integritas (X1) terhadap Kinerja (Y) dapat diketahui bahwa nilai t-statistik 4,050 > t-tabel 1,96 memiliki makna yaitu pengaruh antara variabel Integritas (X1) terhadap Kinerja (Y) adalah signifikan, selanjutnya nilai $P$-Value $0,000<0,05$ yang memiliki makna Hal diterima. Berdasarkan hasil pengujian hipotesis tersebut dapat diketahui bahwa variabel integritas (X1) memiliki pengaruh terhadap variabel kinerja (Y).

\section{Hasil Pengujian Hipotesis Pengaruh Parsial Kecerdasan Emosional (X2) Terhadap Kinerja (Y)}

Berdasarkan hasil pengujian hipotesis pengaruh parsial Kecerdasan Emosional (X2) terhadap Kinerja (Y) dapat diketahui bahwa nilai t-statistik 3,869 > t-tabel 1,96 memiliki makna yaitu pengaruh antara variabel Kecerdasan Emosional (X2) terhadap Kinerja (Y) adalah signifikan, selanjutnya nilai $P$-Value $0,000<0,05$ yang memiliki makna $\mathrm{Ha} 2$ diterima. Berdasarkan hasil pengujian hipotesis tersebut dapat diketahui bahwa variabel 
Kecerdasan Emosional (X2) memiliki pengaruh terhadap variabel kinerja $(\mathrm{Y})$.

\section{Hasil Pengujian Hipotesis Pengaruh Simultan Integritas (X1) Dan Kecerdasan Emosional (X2) Terhadap Kinerja (Y)}

Berdasarkan hasil pengujian hipotesis pengaruh simultan Integritas (X1) dan Kecerdasan Emosional (X2) terhadap Kinerja (Y) dapat diketahui nilai t-statistik 25,195>t-tabel 1,96 memiliki makna bahwa pengaruh antara Integritas (X1) dan Kecerdasan Emosional (X2) Terhadap Kinerja (Y) adalah signifikan . Selanjutnya nilai $P$ Value $0,000<0,05$ yang memiliki makna Ha3 diterima. Artinya variabel Integritas (X1) Dan Kecerdasan Emosional (X2) secara bersamaan memiliki pengaruh terhadap Kinerja (Y).

\section{Pembahasan Deskriptif Integritas} Anggota Kepolisian Polsek Cikarang Timur

Total skor yang didapatkan sebesar 4.148 dengan rata-rata 244 hal ini menunjukkan bahwa integritas seluruh anggota Kepolisian Polsek Cikarang Timur berada dalam criteria setuju, artinya integritas seluruh anggota Kepolisian Polsek Cikarang Timur baik. Berdasarkan hasil penelitian dengan 12 indikator yang diuraikan dalam 17 pernyataan, pernyataan dengan skor tertinggi yaitu terdapat pada pernyataan "Terkadang saya tidak amanah dalam melaksanakan tugas yang diberikan kepada saya karena ada suatu hal yang mendesak", hal ini menunjukkan bahwa anggota Kepolisian Polsek Cikarang Timur merasa kurang amanah pada saat situasi yang mendesak sehingga hal tersebut dapat mengurangi integritas individu dan dapat mempengaruhi kualitas kinerja anggota terhadap institusi. Selanjutnya indicator dengan skor terendah ada pada pernyataan "Saya dapat mengendalikan diri dalam setiap kondisi", hal ini menunjukan bahwa anggota Kepolisian Polsek Cikarang Timur merasa kurang mampu mengendalikan diri dalam setiap keadaan yang dihadapinya.

\section{Pembahasan Deskriptif Kecerdasan Emosional Anggota Kepolisian Polsek Cikarang Timur}

Total skor yang didapatkan sebesar 4.454 dengan rat-rata $223 \mathrm{Hal}$ ini menunjukkan bahwa kecerdasan emosional seluruh anggota Kepolisian Polsek Cikarang Timur berada dalam criteria setuju, artinya kecerdasan emosional seluruh anggota Kepolisian Polsek Cikarang Timur baik. Berdasarkan hasil penelitian dengan 20 indikator, pernyataan dengan skor tertinggi yaitu terdapat pada pernyataan "Saya sangat percaya diri dalam bertindak atas kemampuan yang ada dalam diri saya", hal ini menunjukan bahwa anggota Kepolisian Polsek Cikarang Timur merasa dalam menjalankan tugas sangat percaya diri dengan kemampuan yang dimilikinya sehingga kepercayaan diri tersebut 
dapat mempengaruhi kualitas kinerja anggota terhadap institusi. Selanjutnya indicator dengan skor terendah ada pada pernyataan "Saya mampu memberikan gagasan-gagasan baru", hal ini menunjukan bahwa anggota Kepolisian Polsek Cikarang Timur merasa kurang mampu menyampaikan gagasan atau inovasi baru kepada institusi.

\section{Pembahasan Deskriptif Kinerja} Anggota Kepolisian Polsek Cikarang Timur

Total skor yang didapatkan sebesar 4.352 dengan rata-rata $242 \mathrm{Hal}$ ini menunjukkan bahwa kinerja seluruh anggota Kepolisian Polsek Cikarang Timur berada dalam criteria setuju, artinya kinerja seluruh anggota Kepolisian Polsek Cikarang Timur sudah baik. Berdasarkan hasil penelitian dengan 17 indikator yang diuraikan dalam 18 pernyataan, pernyataan dengan skor tertinggi yaitu terdapat pada pernyataan "Saya dapat memberikan gagasan baru kepada Polsek Cikarang Timur", hal ini menunjukan bahwa anggota Kepolisian Polsek Cikarang Timur dapat memberikan gagasan baru sehingga dapat meningkatkan kinerja. Selanjutnya indicator dengan skor terendah ada pada pernyataan "Saya selalu merasa empati terhadap apa yang terjadi pada rekan kerja saya", hal ini menunjukkan bahwa anggota Kepolisian Polsek Cikarang Timur memiliki jiwa empati yang rendah terhadap rekan kerja.

\section{Pembahasan Verifikatif}

\section{Hasil Pengujian Hipotesis Pengaruh Parsial Integritas (X1) Dan Kecerdasan Emosional (X2) Terhadap Kinerja (Y)}

Berdasarkan hasil pengujian yang dilakukan secara parsial dengan boostrapping - path coefficients dapat diketahui nilai t-statistikin tegritas sebesar 4,050 > t-tabel 1,96 artinya memiliki pengaruh positif dengan pengaruh secara parsial sebesar 47,2\% terhadap kinerja. Selanjutnya hasil hipotesis menunjukkan variabel integritas memiliki pengaruh secara parsial terhadap kinerja.

Selanjutnya, hasil pengujian yang dilakukan secara parsial melalui boostrapping-path coefficients dapat diketahui nilai t-statistik kecerdasan emosional sebesar 3,869>t-tabel 1,96 artinya memiliki pengaruh positif dengan pengaruh secara parsial sebesar $45,4 \%$ terhadap kinerja. Selanjutnya hasil hipotesis menunjukkan variabel kecerdasan emosional memiliki pengaruh secara parsial terhadap kinerja.

Hasil Pengujian Hipotesis Pengaruh Simultan Integritas (X1) Dan Kecerdasan Emosional (X2) Terhadap Kinerja (Y)

Berdasarkan hasil pengujian yang dilakukan secara simultan melalui boostrapping-R-Square dapat diketahui nilai $R$ Square sebesar 0,816 dan termasuk ke adalah kriteria kuat. 
Artinya pengaruh variabel Integritas (X1) dan Kecerdasan Emosional (X2) terhadap Kinerja (Y) sebesar 81,6\% dan sisanya sebesar $18,4 \%$ dijelaskan oleh variabel lain yang tidak diteliti dalam penelitian ini.

\section{PENUTUP}

\section{SIMPULAN}

1. Integritas Anggota Kepolisian Polsek Cikarang Timur

Variabel Integritas menggunakan 12 indikator dengan 17 pernyataan, pernyataan dengan skor tertinggi yaitu terdapat pada pernyataan "Terkadang saya tidak amanah dalam melaksanakan tugas yang diberikan kepada saya karena ada suatu hal yang mendesak" dan pernyataan dengan skor terendah yaitu terdapat pada pernyataan "Saya dapat mengendalikan diri dalam setiap kondisi." Berdasarkan hasil indikatorindikator variabel integritas diperoleh total skor sebesar 4.418 dengan rata-rata skor sebesar 244 berada pada rentang skala 206,6 - 247,8 yang memiliki arti berada pada kriteria setuju. Hal tersebut menunjukkan bahwa Integritas seluruh anggota kepolisian Polsek Cikarang Timur secara umum sudah baik dan mampu meningkatkan kinerja anggota.

\section{Kecerdasan Emosional Anggota} Kepolisian Polsek Cikarang Timur

Variabel Kecerdasan Emosional menggunakan 20 indikator, pernyataan dengan skor tertinggi yaitu terdapat pada pernyataan "Saya sangat percaya diri dalam bertindak atas kemampuan yang ada dalam diri saya" dan pernyataan dengan skor terendah yaitu terdapat pada pernyataan "Saya mampu memberikan gagasan-gagasan baru" berdasarkan hasil indikator-indikator variabel kecerdasan emosional diperoleh total skor sebesar 4.454 dengan rata-rata skor sebesar 223 berada pada rentang skala 206,6 - 247,8 yang memiliki arti berada pada kriteria setuju. Hal tersebut menunjukkan bahwa Kecerdasan Emosional seluruh anggota kepolisian Polsek Cikarang Timur secara umum sudah baik dan mampu meningkatkan kinerja anggota.

3. Kinerja Anggota Kepolisian Polsek Cikarang Timur

Variabel Kinerja menggunakan 17 indikator dengan 18 pernyataan, pernyataan dengan skor tertinggi yaitu terdapat pada pernyataan "Saya dapat memberikan gagasan baru kepada Polsek Cikarang Timur" dan indikator dengan skor terendah ada pada pernyataan "Saya selalu merasa empati terhadap apa yang terjadi pada rekan kerja saya". Berdasarkan hasil indikator-indikator variabel kinerja diperoleh total skor sebesar 4.352 dengan rata-rata skor sebesar 242 berada pada rentang skala 206,6 - 247,8 yang memiliki arti berada pada kriteria setuju. Hal tersebut menunjukkan bahwa Kecerdasan Emosional seluruh anggota kepolisian Polsek Cikarang Timur secara umum sudah baik. 
4. Pengaruh Secara Parsial Integritas (X1) Terhadap Kinerja (Y)

Berdasarkan hasil pengujian yang dilakukan secara parsial melalui boostrapping- path coefficients dapat diketahui bahwa nilai t-statistik 4,050 > t-tabel 1,96 memiliki makna yaitu pengaruh antara variabel Integritas (X1) terhadap Kinerja (Y) adalah signifikan, selanjutnya nilai $P$-Value $0,000<0,05$ yang memiliki makna Ha1 diterima. Berdasarkan hasil pengujian hipotesis tersebut dapat diketahui bahwa variabel integritas (X1) memiliki pengaruh terhadap variabel kinerja $(\mathrm{Y})$.

5. Pengaruh Secara Parsial Kecerdasan Emosional (X2) Terhadap Kinerja (Y)

Berdasarkan hasil pengujian yang dilakukan secara parsial melalui boostrapping- path coefficients dapat diketahui bahwa nilai t-statistik 3,869 > t-tabel 1,96 memiliki makna yaitu pengaruh antara variabel Kecerdasan Emosional (X2) terhadap Kinerja (Y) adalah signifikan, selanjutnya nilai $P$ Value $0,000<0,05$ yang memiliki makna Ha2 diterima. Berdasarkan hasil pengujian hipotesis tersebut dapat diketahui bahwa variabel Kecerdasan Emosional (X2) memiliki pengaruh terhadap variabel kinerja (Y).

6. Pengaruh Secara Simultan Antara Integritas (X1) Dan Kecerdasan Emosional (X2) Terhadap Kinerja (Y)

Berdasarkan hasil pengujian yang dilakukan secara simultan melalui
boostrapping-R-Square dapat diketahui bahwa nilai t-statistik 25,195 > t-tabel 1,96 memiliki makna bahwa pengaruh antara Integritas (X1) dan Kecerdasan Emosional (X2) Terhadap Kinerja (Y) adalah signifikan. Selanjutnya nilai $P$ Value $0,000<0,05$ yang memiliki makna Ha3 diterima. Artinya variabel Integritas (X1) Dan Kecerdasan Emosional (X2) secara bersamaan memiliki pengaruh terhadap Kinerja (Y).

\section{SARAN}

1. Berdasarkan hasil penelitian mengenai variabel Integritas, terdapat indicator self-control yang memiliki nilai skor total terendah dengan pernyataan "Saya mampu mengendalikan diri saya dalam pengambilan keputusan". Dengan hal tersebut maka ke depannya instansi diharapkan dapat memberikan pengetahuan dan pelatihan yang lebih dalam tentang integritas kepada seluruh anggota agar seluruh anggota dapat mengendalikan diri dalam pengambilan keputusan sesuai dengan nilai dan norma yang berlaku sehingga dapat membantu mencapai tujuan institusi. Bentuk pelatihan yang dimaksud berupa pendidikan pelatihan peningkatan kemampuan untuk seluruh anggota, pelatihan pendidikan integritas moral dan pendidikan integritas ke propesionalan anggota.

2. Berdasarkan hasil penelitian mengenai variabel Kecerdasan 
Emosional, terdapat indicator relationship management yang memiliki nilai skor total terendah dengan pernyataan "Saya mampu memberikan gagasan-gagasan baru". Dengan hal tersebut maka ke depannya instansi diharapkan lebih menanamkan budaya organisasi kepada seluruh anggota, memberikan pengertian tentang permasalahan yang sedang terjadi atau yang akan terjadi dan memberikan tantangan pekerjaan berupa target penyelesaian masalah yang terjadi di masyarakat kepada seluruh anggota apabila seluruh anggota dapat menyelesaikan tantangan pekerjaan, maka pimpinan akan memberi reward sehingga seluruh anggota akan lebih peka terhadap lingkungan sekitar, dapat mencari solusi dan semangat memberikan gagasan baru untuk kemajuan institusi.

3. Berdasarkan hasil penelitian mengenai variabel Kinerja, terdapat indikator empati yang memiliki nilai skor total terendah dengan pernyataan "Saya selalu merasa empati terhadap apa yang terjadi pada rekan kerja saya". Dengan hal tersebut maka ke depannya institusi diharapkan membuat suasana institusi lebih hangat dengan cara mengadakan rapat intern antar unit dimana dalam rapat tersebut membahas tentang rencana kegiatan apa saja yang akan dilaksanakan pada hari itu dan membahas tentang kendala yang dialami oleh masing-masing anggota agar antaranggota dapat lebih memahami keadaan sesame sehingga dapat menumbuhkan rasa empati dan dapat bekerjasama lebih baik lagi untuk mencapai kinerja yang baik dan cara selanjutnya yang dapat dilakukan untuk meningkatkan rasa empati anggota yaitu dengan sesekali mengadakan family gatering agar seluruh anggota dapat lebih dekat dengan rekan kerja.

\section{DAFTAR PUSTAKA}

Dunggio, S. (2020). PUBLIK: Pengaruh Budaya Organisasi Terhadap Kinerja Pegawai di Kantor Camat Dungingi Kota Gorontalo. Publik:Jurnal Manajemen Sumber Daya Manusia, Administrasi dan Pelayanan Publik, 7(1), 1-9. https://doi.org/10.37606/publik v7i1.114

Hadju, L., \& Adam, N. (2019). Pengaruh Budaya Organisasi Terhadap Kinerja Pegawai Pada Dinas Perhubungan Kabupaten Bone Bolango. Publik: Jurnal Manajemen Sumber Daya Manusia, Administrasi Dan Pelayanan Publik, 6(2), 125-135. https://doi.org/10.37606/publik.v6i 2.14

Hussein, A. S. (2015). Penelitian Bisnis dan Manajemen Menggunakan Partial Least Squares ( PLS ) dengan smartPLS 3 . 0 .

Kepala Kepolisian Negara Republik Indonesia. Peraturan Kepala Kepolisian Negara Republik Indonesia Nomor 11 Tahun 2012 Tentang Penyusunan Penetapan Kinerja Di Lingkungan Kepolisian Negara Republik Indonesia (2012). 
Kepala Kepolisian Negara Republik Indonesia. Peraturan Kepolisian Negara Republik Indonesia Nomor 2 Tahun 2018 Tentang Penilaian Kinerja Anggota Kepolisian Negara Republik Indonesia Dengan Sistem Manajemen Kinerja (2018).

Nazir, M. (2011). Metode Penelitian. Jakarta: Ghalia Indonesia.

Ridhawati, A. (2016). Pengaruh Kecerdasan Emosional Terhadap Kinerja Karyawan Pada PT. Sang Hyang Seri (Persero) Cabang Sidrap.

Rizky Kurniansyah. (2016). Pengaruh Emotional Intelligence Dan Motivasi Terhadap Kinerja Pegawai Dinas Pertanian Tanaman Pangan Dan Hortikultura Provinsi Lampung.

Sofyani, H. (2016). Modul Praktik Partial Least Square ( PLS ).

Sudaryo, Y., Ariwibowo, A., \& Sofiati, N. A. (2018). Manajemen Sumber Daya Manusia Kompensasi Tidak Langsung Dan Lingkungan Kerja Fisik. (T. Erang, Ed.) (1st ed.). Yogyakarta: Andi.

Sugiyono. (2018). Metode Penelitian Kuantitatif. (Setiyawami, Ed.). Bandung: Alfabeta.

Sukmana, D. T., \& Indarto. (2018). Pengaruh Kepemimpinan Dan Integritas Terhadap Kinerja Anggota Polisi Melalui Kepuasan Kerja Sebagai Variabel Intervening, 128-141.
Wigiadi, \& Sunyoto, Y. (2017). Integritas Memediasi Kode Etik Dan Kepuasan Kerja Terhadap Kinerja (Studi Kasus Akademik Kepolisian Semarang), (20). 